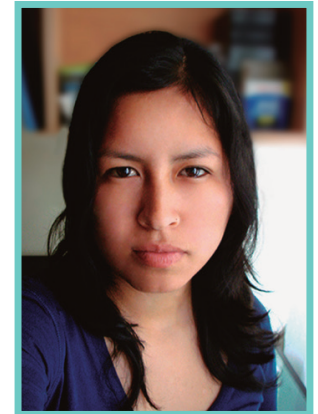

Ruth Huarcaya Aliaga

\title{
APORTES DE LAS TIC PARA LA CREACIÓN DE PORTAFOLIOS VIRTUALES
}

\section{RESUMEN}

Este artículo propone el uso práctico de una de las estrategias innovadoras aportadas en el marco de las Tecnologías de la Información y Comunicación (TICs), a las aulas universitarias; como es la creación del portafolio virtual, usando Weebly, a fin de demostrar la facilidad de crear nuevas herramientas didácticas para transformar nuestra práctica docente.

\section{PALABRAS CLAVE}

Tecnología de la información y comunicación (TIC), portafolio virtual, portafolio de evidencia e innovación.

\section{ABSTRAC}

This article aims to propose the practical use of innovative strategies provided in the context of Information Technology and Communication (TIC) to university classrooms; as is the creation of the virtual portfolio, using Weebly, to demonstrate the ease of creating new teaching tools to transform our teaching.

\section{KEYWORDS}

Information Technology and Communication (ICT), virtual portfolio, portfolio de evidence and innovation.

\section{INTRODUCCIÓN}

T a innovación y constante transformación de las tecnologías de la información y comunicación (TIC) —en todos los ámbitos sociales, exige de la práctica docente universitaria, un nuevo rol transformador en donde su eficacia depende por completo de las habilidades que tanto el alumno como el profesor aporten al proceso de enseñanza-aprendizaje, donde el Internet es una ventana a estas experiencias.

1. Integración de las TICs a las aulas universitarias

La integración de las TIC en las Universidades mejora la enseñanza y el aprendizaje de diferentes cursos y aumenta la motivación tanto para los estudiantes como para los profesores, creando ambientes de aprendizaje con interacción más dinámica entre maestro y estudiante, incrementando la colaboración y el trabajo en equipo.

Por su parte; Cabero, López y Llorente (2012), nos dicen que "con la aparición de entornos interactivos que podíamos denominar como 2.0, caracterizados por ser más abiertos, 
colaborativos y gratuitos, permiten al docente poder incorporarlos como recursos didácticos para la implementación de metodologías más flexibles, activas y participativas" (p. 29).

Sánchez (2002), distingue tres niveles para llegar a la integración de las TIC:

a) Apresto, se refiere a los primeros pasos en el conocimiento y uso de las TIC.

b) Uso, implica un mayor conocimiento de las TIC y el usarlas para diversas tareas, pero sin un propósito curricular claro todavía.

c) Integración curricular de las TIC, significa más bien orientarlas para los objetivos curriculares para un fin educativo específico.

d) Por lo que, “...utilizar las nuevas tecnologías de la información y la comunicación, para realizar las mismas cosas con las tecnologías tradicionales, es un gran error. Las nuevas tecnologías, nos permiten realizar cosas completamente diferentes a las efectuadas con las tecnologías tradicionales; de ahí que un criterio, para su incorporación, no pueda ser exclusivamente, el hecho que nos permitan hacer las cosas de forma más rápida, automática y fiable." (Cabero, 2003. p. 106)

"En su utilización debemos buscar el crear nuevos escenarios y entornos más ricos y variados para el aprendizaje, y adaptarlas a las nuevas demandas y exigencias de los nuevos retos educativos." Cabero (2007. p. 8)

\section{Los portafolios virtuales}

Para Hernández, Reyes y López (2013), “los portafolios electrónicos son instrumentos didácticos para la mejora de la praxis educativa al facilitar la reflexión y construcción de conocimientos, la planificación de las tareas educativas, la responsabilidad e introspección individual" (p. 2).

Fraga y Gewerc (2009), expresan que el portafolio se transforma en ese espacio que da cuenta del recorrido y de los productos, de las producciones individuales y colectivas, de las reflexiones que se van desarrollando durante el camino. Concuerda con la idea básica de que el aprendizaje comprende un continuo de experiencias que facilitan a los alumnos oportunidades para construir su propia visión de los contenidos a través de un compromiso activo con su proceso de aprender (p. 5).

\section{Implementación de un portafolio virtual usando Weebly}

Las TICs, por lo tanto, a través del portafolio virtual, proporcionarán la creación de entornos activos, en el sentido que potenciarán el aprendizaje constructivo; el "hacer" y el "saber hacer" en lo que se refiere a la realización de actividades. Atendiendo así, al rol de los usuarios como creadores de conocimiento, por lo que, los nuevos entornos formativos deberán contar con los entornos de aprendizaje personal que crearán los propios estudiantes.

Por otra parte, tendremos que contemplar las posibilidades que nos ofrecen los software, para crear entornos más dinámicos y flexibles, y que nos permiten responder en función de las características cognitivas, de los estudiantes, lo que nos conduce a diseñar medios en función del tipo de interacción, respuesta e historial, que mantenga con el sujeto, a fin de que haga que el programa se comporte de una forma u otra (Cabero, 2008).

\section{1 ¿Qué es Weebly y qué permite crear?}

Weebly, es una plataforma dedicada a la creación de páginas Web gratuitas y de pago. Fue creada en 2006 por David Rusenko, Chris Fanini, y Dan Veltri. Las características de Weebly son poseer docenas de diseños para 
desarrollar un sitio Web, así como una interfaz sencilla que permite arrastrar y soltar los distintos elementos que compondrán la página.

Las funciones de Weebly, entonces, se definen en dos características esenciales. Una de ellas es la recién mencionada de arrastrar y soltar los elementos para diseñar lo que queremos. La otra se encuentra bajo la premisa de "lo que ves, es lo que obtienes".

El nivel de personalización de un portafolio virtual con Weebly, se logrará con la misma facilidad, es posible agregar títulos, textos, texto e imagen, imagen, galería de imágenes, galería de imágenes interactivas y vincular videos de YouTube, además de otras páginas al sitio, inclusive se puede agregar una herramienta de blog.

Si bien el plan básico es gratis, hay además distintos planes de suscripción, según el que se escoja será posible acceder a mayores prestaciones.

\subsection{Procedimientos para crear el portafolio virtual en Weebly}

A continuación detallaremos los pasos para crear el sitio Web:

1. Ingresar a: Weebly.com

2. Registrarse.

3. Escoger un tema o diseño. Clic en elegir.

4. Para construir, Weebly nos da dos opciones: Primera opción, elegir un diseño preestablecidoolasegundaopción, construir arrastrando los iconos: título, texto, texto e imagen, imagen, galería de imágenes, galería de imágenes interactivas y videos de YouTube. Construimos arrastrando los botones de izquierda al centro.

5. También se puede agregar más páginas internas. Ir a la pestaña Páginas y dar clic al botón Agregar, luego escribir el nombre. Regresar a la pestaña Construir para diseñar la nueva página.

6. Una vez terminado el proceso de construcción pasamos al de publicación, haciendo clic en el botón Publicar (ubicado en la parte superior derecha).

- Se recomienda, completar los datos y opciones que nos pidan, como por ejemplo: crear un nombre para el sitio Web (optar por solo escribir en el primer recuadro, por ser gratuito).

7. Una vez visualizada la disponibilidad. Clic en el botón Continuar, dar clic en la dirección de color azul, para visualizar el sitio Web creado.

\section{Conclusión}

El uso del portafolio virtual es un recurso didáctico interesante para el docente y los estudiantes; ya que garantiza la construcción del proceso de enseñanza-aprendizaje-evaluación, y por ende, de la calidad e innovación educativa universitaria a lo largo de la vida, pues gestiona aprendizajes significativos y es la evidencia de que el estudiante cuenta con las competencias que se solicitan en el curso.

\section{REFERENCIAS}

Cabero, J.; Romero, R. (2007). Diseño y producción de TIC para la formación. Barcelona: UAS.

Cabero, J.; López Meneses, E. y Llorente, M. C. (2009). La docencia universitaria y las tecnologías Web 2.0 renovación e innovación en el Espacio Europeo. Sevilla: Mergablum.
Cabero, J.; López, E. \& Llorente, M. C. (2012). E-portafolio universitario como instrumento didáctico 2.0 para la reflexión, evaluación e investigación de la práctica educativa en el Espacio Europeo de Educación Superior. Virtualidad, Educación y Ciencia, 3(4), 27-45. Recuperado de http:// tecnologiaedu.us.es/tecnoedu/images/stories/jca82.pdf 